Max-Planck-Institut für demografische Forschung

Max Planck Institute for Demographic Research

Konrad-Zuse-Strasse 1 - D-18057 Rostock - GERMANY

Tel +49 (0) 3812081 - 0; Fax +49 (0) 3812081 - 202;

http://www.demogr.mpg.de

MPIDR WORKING PAPER WP 2004-014

APRIL 2004

The Contextual Database of the

Generations and Gender Program:

Overview, Conceptual Framework

and the Link to the Generations and

Gender Survey

Martin Spielauer (spielauer@ demogr.mpg.de)

This working paper has been approved for release by: Vladimir M. Shkolnikov (shkolnikov@ demogr.mpg.de),

Head of the Laboratory for Demographic Data.

(C) Copyright is held by the authors.

Working papers of the Max Planck Institute for Demographic Research receive only limited review.

Views or opinions expressed in working papers are attributable to the authors and do not necessarily reflect those of the Institute. 


\title{
The Contextual Database of the Generations and Gender Program: Overview, Conceptual Framework and the Link to the Generations and Gender Survey Martin Spielauer
}

\begin{abstract}
This paper follows two aims. First it intends to give an overview of the contextual database of the Generations and Gender Program and how it is linked to the Generations and Gender Survey. Secondly, it provides a documentation of the approaches taken towards the conceptual definition and construction of the database. The document consists of two parts. The first gives a brief description of the underlying ideas of the database and the approach taken in order to develop its conceptual framework and construct the database. The second part is a note on the link between the Generations and Gender Survey and the contextual database. Starting from the GGS questionnaire, the main interfaces between micro data and contextual domains are investigated.
\end{abstract}

\section{Introduction}

This paper is based on a document presented at the $9^{\text {th }}$ Consortium Board meeting of the Generations and Gender Program in Paris, March 2004. It aims to give an introduction of the contextual database of the Generations and Gender Program and how it is linked to the Generations and Gender Survey. It also provides a documentation of the ongoing work and the approaches taken towards the conceptual definition and construction of the database. The appendix contains information on existing databases that provide relevant data-sources and/or interesting case-studies of related projects.

The document consists of two parts. The first gives a brief description of the underlying ideas of the database and the approach taken in order to develop its conceptual framework and to construct the database. The second part is a note on the link between the Generations and Gender Survey and the contextual database. Starting from the GGS questionnaire, the main interfaces between micro data and contextual domains are analyzed. 


\section{Approaches: conceptual framework and database development}

\subsection{The idea of a contextual database}

The idea of the development of a contextual database to complement the data collection on the individual level was already expressed in the Family and Fertility Survey program, which preceded the Generations and Gender Program. It was driven by the desire 'to go beyond the analysis of single countries and to consider how differences in context shape the processes that seem to be having an impact on these new family pattern' (Goldscheider 2000). More generally, it is based on (1) the increasing recognition that micro behavior cannot be explained only by relations observed on the micro level and (2) an increasing interest in comparative research. 'Designing a Macro-Context for the Generations and Gender Individual Data' was also the topic of a contribution by Patrick Festy (2001) presented at the first meeting of the Generations and Gender Informal Working Group in 2001. With the installation of the Contextual Database Working Group in 2002, the development of a contextual database became an integral part of the Generations and Gender Program².

The contextual database is a comparative collection of data on a national and subnational level complementing the individual-level data collected in the GGS. It will consist of a core database for all GGP countries, plus country-specific extensions, within a common classification scheme and technical framework. The database makes it possible to analyze the micro-level information collected from individuals in its societal macro-level context and especially supports a multilevel approach to GGP data. The contextual database will include information on laws and policies that effect age and sequencing norms as well as the consequences and risks associated with central life-course events. It will include indicators of general gender and generational relations and a range of social, economic and political indicators.

\subsection{A four-way approach towards a conceptual framework}

The Contextual Database Working Group is currently engaged in the development of the conceptual framework for this database. It follows a four-way approach, first using the GGS questionnaire content itself as departure point. The second approach starts from theories and hypothesis underlying the Generations and Gender Survey as well as from research streams considered helpful for the development of the database

\footnotetext{
${ }^{1}$ Patrick Festy coordinated the Contextual Database Group from its establishment until mid 2003.

${ }^{2}$ Current members of the Contextual Database Group are Martin Spielauer (coordinator, MPIDR), Gerda Neyer (MPIDR), Patrick Festy (INED), Tereza Munzi (LIS), Filomena Racioppi (La Sapienza), Giulia Rivellini (UNICATT), Enrico Bisogno (UNECE PAU), Alphonse MacDonald (UNECE PAU) and Jacques Légaré (Statistics Canada)
} 
framework, e.g. welfare state research. The third approach concerns methodological issues, i.e. the question of how data will be analyzed and how the contextual database can support new innovative analytical methods. Finally, available data(bases) are used as point of departure, both in order to reflect what is feasible regarding data availability and what can be learned from other database projects, frameworks and approaches.

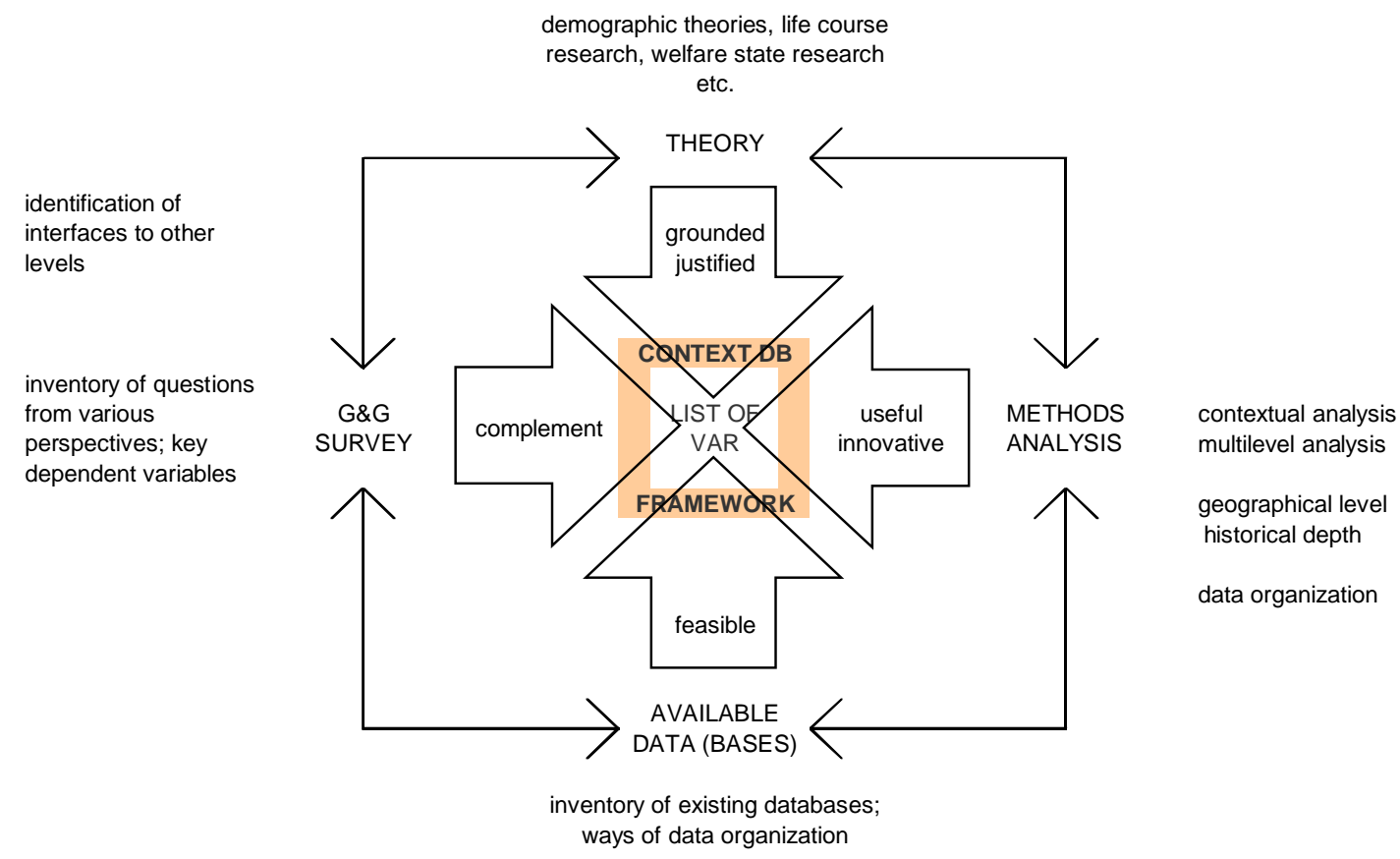

\section{Illustration 1: Approaches towards the database framework}

As the contextual database is to be understood as complementary to the micro data collection of the Generations and Gender Survey, the survey questionnaire constitutes a logical starting point for the development of the conceptual framework. The departure point is a structured inventory of the micro level information collected by the survey in a way that supports the identification of higher-level "systems" corresponding to micro level domains and relations. A way that has proven fruitful in this respect was to structure the survey content from a life-course perspective, which provides a very systematic approach regarding the structuring of complex individual data by different life-course domains and by time. The life-course paradigm is the dominant paradigm in demography and with its emphasis on process and context it is closely linked to current mainstream developments of demographic research including the GGS - and research methods (such as multilevel event-history analysis).

How do these individual life-course data relate to the context? Is there a direct link of life-course domains to contextual domains? The possibility to meaningfully describe individual biographies structured by segmented roles already indicates a close link to the societal context, as it results from societal differentiation. These roles are therefore 
not independent of the macro context of life, such as the welfare state and its institutions. Stated differently, there exists a mapping of the institutional differentiation on the macro level of societies onto life-course domains and the timing, sequencing and synchronization of life-course events. Approaching the development of the database framework from this side can be seen as an attempt to do such a "micro-macro mapping" resulting in a definition of the key domains of the contextual database.

As already indicated by its name, gender and (inter-) generational relations constitute a key area of information collected in the Generations and Gender Survey. Interpersonal relations are investigated in various dimensions, with some of them having a close link to higher-level systems and institutions. Examples are the legal dimension (e.g. being married) and the economic dimension of relations, especially regarding the organization, production and exchange of care. Surveyed information also include received public transfers, pensions and other benefits as well as the use of institutional care and childcare services. These variables directly connect the individual situation to the broader context of the welfare state.

The second approach starts from theories and hypotheses that have guided the development of the Generations and Gender Survey questionnaire and relate to its key dependent variables, which are childbearing, partnership formation/dissolution, transition to adulthood, living arrangements and economic activity. The novelty of the survey lies in the broad spectrum of covariates, reflecting the multidisciplinary approach of the program. The set of related theories and hypothesis is accordingly broad. By means of a series of consultations of experts of different research fields and disciplines, the contextual database group aims at incorporating their expertise and to maximize the usability of the contextual database for multidisciplinary demographic research. Regarding the development of the conceptual framework for the collection of policy data, comparative welfare-state research provides particularly useful concepts. An outline of the Generations and Gender dimensions in welfare-state policies can be found in a contribution by Gerda Neyer (2002).

The third approach starts from methodological reflections - "how" the database will be used in connection with the survey data. One of the explicit goals of the database is to enable and promote a multilevel and comparative approach of analysis. Together with the innovative design of the Generations and Gender Survey, especially its combination of retrospective and prospective components, this places high demands on such a contextual data collection. In order to meet the historical depth of the Generations and Gender Survey, we have to go beyond a cross-sectional macro period approach. Combining micro and macro data within the same analytical framework requires that we have to be able to link individuals to "their" context geographically, by group membership (e.g. regarding the eligibility for policy provisions) and over 
time. The second main aim, namely the support of comparative analysis, emphasizes another key requirement of the data collection, i.e. the comparability of the collected contextual data. Many of the related issues are covered in contributions by Filomena Racioppi and Giulia Rivellini (2002) to the group.

When building a new database, we have to take a close look at existing databases, their organization (e.g. classification schemes) and content. As we will mainly depend on existing data sources in order to "feed" the contextual database, this approach mainly focuses on feasibility topics. One of the challenges is the wide range of countries participating in the Generations and Gender Program. Particularly for nonOECD and EU countries, many data are not "readily available" and have to be collected alongside the program. The same holds true for data on regional levels in most countries.

The study of other databases also provides an opportunity to learn from their different conceptual and technical approaches and the way they provide information. The range of approaches is especially broad regarding policy data, ranging from collections of policy descriptions, quantitative time series data (e.g. of expenditures) to computer codes for the calculation of benefits at the individual household level, as in tax-benefit microsimulation models. Decisions about which approach will be taken and how the database shall be set up require a careful study of the existing databases - and a linkage to the potential of the GGS and its research topics.

The creation of a contextual database is one of the various innovations of the Generations and Gender program. It will enable an interpretation of the micro-level information collected from individuals and families in the surveys in its societal macro-level context and the provision of much richer information on the causes and potential consequences of family, gender and intergenerational changes. The contextual database 'will thus permit researchers to position individuals and families in a more nuanced setting than in any previous comparative demographic research' ${ }^{3}$.

\subsection{Operationalization of the four-way approach}

Most activities, discussions and written contributions of the Contextual Database Working Group can be grouped around these four main approaches. In a first phase, under the coordination of Patrick Festy, several background documents were produced, concerning the development of ideas for a contextual database (Festy 2001), useful concepts of welfare state research regarding the conceptual framework (Neyer 2001) and methodological issues (Racioppi, Rivellini 2001). The contextual

\footnotetext{
${ }^{3}$ Quoted from the Website of the Max Planck Institute for Demographic Research http://www.demogr.mpg.de/general/structure/division2/lab-ceffd/151.htm
} 
database group also compiled a first list of various existing databases. The results have recently been summarized by Patrick Festy (2004).

The work of the group has entered the second phase since summer 2003, aiming at the development of the concrete conceptual framework of the database which eventually will result in the definition of all included variables, a plan to collect these data and the technical implementation of the database. The following illustration gives an overview of the main goals of our four-way approach.

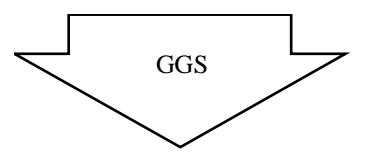

TOPICS

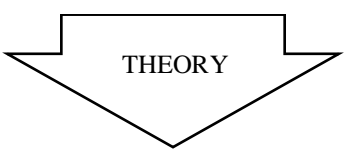

QUESTIONS

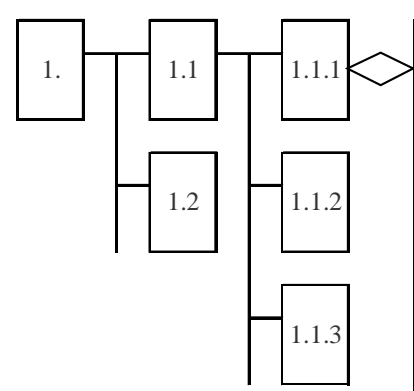

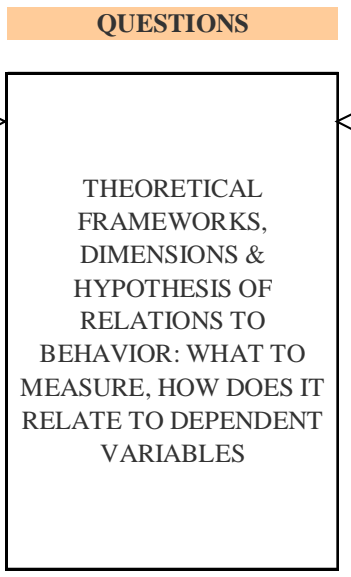

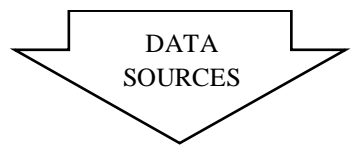

VARIABLES

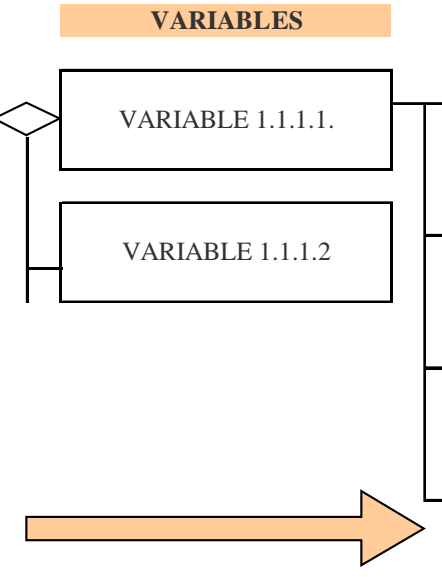

Goals
Close link between

CDB and GGS;

definition of database

topics and priorities;

coordination of wave II

questionnaire

development with $\mathrm{CDB}$

development

\section{"choosing the right topics"}

Consistent theory-based conceptual framework of CDB. Identification of key relationships between contextual domains and dependent variables of GGS

$$
\begin{gathered}
\text { "asking the right } \\
\text { questions" }
\end{gathered}
$$

Choice and definition of most useful variables making maximum use of existing sources, assuring cross-national comparability; networking and cooperation.

\section{"the best feasible set of variables..."}

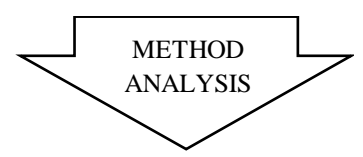

PROPERTIES

DEFINITION: WHAT? WHO? WHEN? WHERE?

REPRESENTATION: TABLES, CODE, GRAPHS

VALUES

CLASSIFICATION

Optimizing usability for analysis, support of multi-level approaches; choice of the appropriate geographical level and historical depth for all variables; appropriate database layout

"..at the right level and depth"

Illustration 2: Approaches and goals 


\section{The link between GGS and contextual data}

In order to describe the information content of a survey, one can take various approaches. In this paragraph, we aim at describing the survey in a way that supports the identification of the interfaces of the collected individual data with contextual data. In order to do so, we will look at the data from various different perspectives. We will start from a life-course perspective that is very useful also regarding the structuring of complex individual data by different life course domains and by time. We will then look at the dimensions of personal relations captured by the survey. The GGS collects detailed data on labor-market activity, home production (care, household tasks etc.) and related exchange relations. It also includes public transfers, pensions and other benefits as well as used institutional care and childcare services. These variables connect the individual situation to the broader context of the welfare state, and we will use a welfare state perspective in the analysis of related aspects. Following this route, we will cover all collected variables, highlight the main dependent variables and the key links and interfaces of micro- and contextual data.

\subsection{The individual life course}

The life course refers to a sequence of socially defined events and roles that the individual enacts over time. These roles and the transitions from one role to another are central issues in the GGS and constitute key dependent variables: partnership formation and dissolution, childbearing, changing living arrangements etc. Contrary to the life-cycle concepts, which are widely used, e.g. in economics or psychology, and which are based on a predetermined "typical" sequence of roles, episodes of life or expected behaviors, the life-course concept permits the study of changing role patterns and of the interactions between different domains or careers, such as education, jobs, partnerships, births and disability. Key elements of the life course paradigm are human agency and individual goal orientation as well as "strategic adaptation", by timing of events in the presence of conflicting goals. In demographic research, the life-course framework links the traditional concepts of period, age and cohort to the fourth component of the timing of lives. The life course perspective also goes hand in hand with a certain description of human biographies as event histories with clearly defined states and events belonging to different domains. In the GGS, we can distinguish several of such domains, many of them further distinguishing events by various dimensions. We can distinguish five main careers ${ }^{4}$ (or domains)

- The "Life" career, with a "general" dimension - being alive, res. the events birth and death - and the health dimension, with survey data collected on illnesses, disabilities, care needs, wellbeing and some limited history information.

\footnotetext{
${ }^{4}$ This classification is only one of various possible categorizations
} 
Information on limitations in daily activities are collected for all household members as well as for parents and children in order to get information on possible care needs in the family network.

- Activity careers: The survey distinguishes various main activities such as working, retirement, on parental leave, unemployed, in education etc. Information on the main activity is collected for all household members. The questions regard the respondent's and partners current job and/or education and intentions to start or resume work, e.g. after leave periods. Full histories are planned to be collected at the second wave.

- Residential careers, with the dimensions of geographical location, dwelling type and living arrangements (co-residence). The first wave of the GGS only collects limited biographical information such as the place of birth, the main living arrangement until age 15 etc., but detailed information on the current status and intentions of changing the dwelling, location and/or living arrangements.

- Partnership careers, with the dimensions of legal relation and co-residence. The GGS contains a full history of co-residing partnerships and marriages and divorces. Extensive information is collected on the current partner, especially on activity status, income and fertility.

- Fertility careers, with the dimensions of fecundity and births, including current pregnancies. The GGS contains full birth histories. Due to the increasing age at (first?) birth in many countries, a high emphasis is placed on questions regarding fertility treatment. With births being one of the key dependent variables, extensive information is collected also on fertility intentions.

The following table displays the main questionnaire content by career domains and dimensions, and further distinguishes by time: retrospective questions, current state and prospective questions and intentions. 


\begin{tabular}{|c|c|c|c|c|}
\hline Domain & Dimension & Retrospective & Current & Prospective \\
\hline \multirow[t]{2}{*}{ Life } & general & $\begin{array}{l}\text { birth, death (partner, parents, } \\
\text { children) }\end{array}$ & & \\
\hline & health related & disabled and illness since & $\begin{array}{l}\text { disabilities, health status, } \\
\text { illness, personal care need, } \\
\text { wellbeing }\end{array}$ & expected locus of control \\
\hline \multirow[t]{5}{*}{ Activity } & $\begin{array}{l}\text { All (work, } \\
\text { leave, } \\
\text { education, } \\
\text { military/civil } \\
\text { service, } \\
\text { unemployed, } \\
\text { retired, } \\
\text { homekeeper) }\end{array}$ & in current state since & current activity; satisfaction & \\
\hline & work & $\begin{array}{l}\text { worked last week? Why } \\
\text { stopped last job? }\end{array}$ & $\begin{array}{l}\text { various job characteristics: type, } \\
\text { sector, hours, position, } \\
\text { flexibility; additional job(s), } \\
\text { satisfaction with job security }\end{array}$ & $\begin{array}{l}\text { intention to give up or change } \\
\text { job; for all not currently working: } \\
\text { intentions to start, resume to } \\
\text { work }\end{array}$ \\
\hline & education & highest, finishing date & & $\begin{array}{l}\text { intention to complete or resume } \\
\text { education }\end{array}$ \\
\hline & retirement & date & & $\begin{array}{l}\text { intention to retire, including } \\
\text { opinions of others, factors that } \\
\text { influence decision and assumed } \\
\text { consequences }\end{array}$ \\
\hline & $\begin{array}{l}\text { parental \& care } \\
\text { leave }\end{array}$ & $\begin{array}{l}\text { history (with which children in } \\
\text { leave) }\end{array}$ & type of leave & $\begin{array}{l}\text { possibility and intention to } \\
\text { resume work }\end{array}$ \\
\hline \multirow[t]{3}{*}{$\begin{array}{l}\text { Co-) } \\
\text { Residence }\end{array}$} & Place & $\begin{array}{l}\text { place of birth and at age } 15 ; \text { in } \\
\text { country since }\end{array}$ & & \multirow[t]{2}{*}{$\begin{array}{l}\text { intention to move, including } \\
\text { destination }\end{array}$} \\
\hline & Dwelling & since & $\begin{array}{l}\text { ownership and number of } \\
\text { rooms; satisfaction }\end{array}$ & \\
\hline & Arrangement & & & $\begin{array}{l}\text { intention of leaving parental } \\
\text { home and/or of moving together } \\
\text { with a partner including opinions } \\
\text { of others, factors that influence } \\
\text { decision and assumed } \\
\text { consequences }\end{array}$ \\
\hline \multirow[t]{3}{*}{ Partnerships } & $\begin{array}{l}\text { current } \\
\text { partnership }\end{array}$ & $\begin{array}{l}\text { since, when moving together } \\
\text { and married }\end{array}$ & \multicolumn{2}{|c|}{$\begin{array}{l}\text { quality of partnership; disagreements and handling of conflicts; } \\
\text { thought about break-up? }\end{array}$} \\
\hline & legal & $\begin{array}{l}\text { full history of marriage and } \\
\text { divorce; who started process of } \\
\text { divorce; where children after } \\
\text { break-up }\end{array}$ & & intention to marry \\
\hline & coresidence & $\begin{array}{l}\text { full history of partnerships in co- } \\
\text { residence and reason of } \\
\text { dissolution }\end{array}$ & & $\begin{array}{l}\text { intention to move together with a } \\
\text { partner including opinions of } \\
\text { others, factors that influence } \\
\text { decision and assumed } \\
\text { consequences }\end{array}$ \\
\hline \multirow[t]{3}{*}{ Fertility } & $\begin{array}{l}\text { current } \\
\text { pregnancy }\end{array}$ & \multicolumn{2}{|c|}{$\begin{array}{l}\text { when stopped contraception; begun fertility treatment; wanted? } \\
\text { Wanted from partner? }\end{array}$} & expected birth date \\
\hline & fecundity & $\begin{array}{l}\text { when detected inability to have } \\
\text { children? sterilization; treatment } \\
\text { since; contraception since }\end{array}$ & current status & \\
\hline & births & full history & & $\begin{array}{l}\text { intention to have another child } \\
\text { next } 3 \text { years, in general, total } \\
\text { number; including opinions of } \\
\text { others, factors that influence } \\
\text { decision and assumed } \\
\text { consequences; intentions to } \\
\text { adopt children }\end{array}$ \\
\hline
\end{tabular}

As shown in the table above, the main dependent variables of the survey are childbearing, formation and union dissolution, transition to adulthood and living arrangements. Given the broad coverage of intentions, dependent variables can be both retrospective events and intentions - with the full power of the survey unfolding with the subsequent panel wave which will substantially extend the scope of possible 
analysis (e.g. of the circumstances that influence the realization of intentions or of the ways in which demographic behavior shapes value orientations and attitudes, influences well-being and intergenerational and gender relationships).

How do these individual data relate to context? The description of individual lives by means of event history data is not independent of the context. The possibility to meaningfully describe individual biographies that way is a result of societal differentiation, which leads to a structure of the life course in segmented roles. These roles are therefore not independent of the macro context of life, like the welfare state and its institutions. There exists a mapping of the institutional differentiation on the macro level of societies onto life domains and the segments of the life course. For example, the activity status "on parental leave" depends on the existence of parental leave regulations. This places individual choices into a context that might vary considerable between countries. The following table highlights the key micro-macro links between life course states and macro level institutions.

\begin{tabular}{|c|c|c|}
\hline & $\begin{array}{l}\text { Micro state / } \\
\text { event }\end{array}$ & Macro system \\
\hline \multirow[t]{7}{*}{ Activity Status } & Employed & Labor market \& employment system \\
\hline & Unemployed & Unemployment insurance \\
\hline & $\begin{array}{l}\text { Military \& civil } \\
\text { service }\end{array}$ & $\begin{array}{l}\text { Defense system and (alternative) service } \\
\text { regulations }\end{array}$ \\
\hline & $\begin{array}{l}\text { Maternity \& care } \\
\text { leave }\end{array}$ & Leave regulations \\
\hline & Student & Education system \\
\hline & Retired & Retirement system \\
\hline & Home keeper & $\begin{array}{l}\text { Tax system, social insurance of } \\
\text { dependent family members }\end{array}$ \\
\hline \multirow[t]{3}{*}{ Marital Status } & Married & $\begin{array}{l}\text { Marriage regulations \& obligations; tax } \\
\text { treatment of married couples; incentive } \\
\text { system for unmarried \& single } \\
\text { parenthood }\end{array}$ \\
\hline & Divorced & Divorce regulations; alimonies \\
\hline & Widowed & Widowed pension \\
\hline Parenthood & Pregnancy & $\begin{array}{l}\text { Maternity leave system; job protection; } \\
\text { abortion laws; birth preparation system }\end{array}$ \\
\hline
\end{tabular}


(health checks etc.)

Parent

-> Relations

Health status

Restricted in daily

Health \& elderly care system

activities; in need

of care

Sick

Health insurance system

\subsection{Gender and generational relations}

With it being a "Generations and Gender" Survey, gender and (inter-)generation relations constitute a key area of information collected in the survey. Persons for whom information is collected include all persons in the household, all (ex-) partners, children and parents as well as other persons if they are important providers or receivers in the captured exchange relations (see below). Personal relations are investigated in various dimensions:

- Legal: nature of legal relation such as married, adopted.

- Co-residence: does the person currently live in the household, when did he or she enter or leave the household or vice versa?

- Intensity: how often does the respondent meet the person, how far does he or she live away?

- Satisfaction: how satisfied is the respondent with the relation?

- Quality: some questions aim at measuring the quality of relations, like the occurrence and the way of settling certain problems etc.

- Power and decision making: who decides on the organization of household tasks and childcare or on spending?

- Care relations: main providers and receivers of care, including emotional support.

- Economic exchange: both regarding money (who contributes what to the household income, who decides on spending; transfers and alimonies) and regarding household production of child and elderly care as well as the diverse household tasks.

The economic dimension of gender- and intergenerational relations can be regarded as one of the key areas of the survey. Household production, especially regarding the organization, production and exchange of care are a central link between gender and generational relations. 


\begin{tabular}{lll}
\hline & $\begin{array}{l}\text { Relational } \\
\text { dimension }\end{array}$ & Macro context \\
\hline $\begin{array}{l}\text { Household } \\
\text { production }\end{array}$ & $\begin{array}{l}\text { Organization of } \\
\text { child care }\end{array}$ & $\begin{array}{l}\text { Child care system, care leave regulations, } \\
\text { institutional child care provision }\end{array}$ \\
& $\begin{array}{l}\text { Organization of } \\
\text { elderly care }\end{array}$ & $\begin{array}{l}\text { Elderly care system, legal obligations, } \\
\text { institutional care }\end{array}$ \\
Living arrangement & Co-residence & $->$ Housing \\
\hline
\end{tabular}

\subsection{Socio-economic situation and the welfare state}

The GGS covers the socio-economic situation of the respondent and the household regarding (1) jobs and labor income, (2) non-labor incomes (benefits and transfers), (3) wealth and (4) some selected expenditures on care and household services. Extensive attention is given to both the respondents and his or her partners' paid work if economically active: job position, type and sector of employment, size of company, public/private etc. Regarding the job relation, we can further distinguish its (1) legal dimension (employed, freelance, self-employed etc.), its (2) time dimension: working hours, time arrangement and flexibility including questions on the compatibility with family life and (3) the income dimension: salaries and benefits.

\begin{tabular}{lll}
\hline & $\begin{array}{l}\text { Individual } \\
\text { economic well- } \\
\text { being }\end{array}$ & Macro context \\
\hline General & General wellbeing & $\begin{array}{l}\text { General level of economic development } \\
\text { (GDP etc.), price stability and } \\
\text { distribution of income and wealth }\end{array}$ \\
Income & Work income & Labor market \& employment system \\
& $\begin{array}{l}\text { Transfers and } \\
\text { benefits }\end{array}$ & Tax benefit system, welfare state \\
Housing & Housing situation & $\begin{array}{l}\text { Housing market: prices and market } \\
\text { segregation; ownership vs. private and } \\
\text { public rental market }\end{array}$ \\
\hline
\end{tabular}




\subsection{Values}

The GGS includes a section on attitudes and value orientations on gender and intergenerational relations as well as religiousness. This individual level data is placed in the context of the cultural, political and religious heritage of a country or region and the relative strength of confessions and political orientations.

\subsection{Summary: a graphical representation of the survey content and its context}

The following two figures display the GGS content and linked contextual domains by means of graphical charts. The black boxes refer to persons and contain the main "absolute" variables of the survey, with biographical data organized by life course domains as described above. Links between person are indicated by the orange diamonds containing the "relational variables", i.e. information on the various relations between people. The green diamond denotes "job relations" and links persons to their job (green box). All relational diamonds are linked by two key "exchange" flows, the blue one indicating monetary flows (income including benefits and pensions; blue boxes) and exchange relations, the red one indicating exchange and use of time i.e. working time, care services and other items relating to household production (red boxes).

The second figure adds related contextual domains to the previous figure. Most boxes (the brown ones) refer to the welfare state, i.e. the tax \& benefit and regulatory system which structures the relation between markets, the private sector, families and gender. These domains are connected and three main concepts of welfare state research are highlighted in the graph: (1) policies that impact the dependency of income on market work, i.e. the concept of de-commodification introduced by Esping-Andersen (1980); (2) policies and institutional care provisions that impact the availability of care services outside the family, referring to Esping-Andersen's concept of defamilialization; and (3) policies that structure the gender division of paid and unpaid work, e.g. policies that support dual or single breadwinner models, referring to "gendered agency" concepts as introduced by Korpi (2000).

Besides welfare state institutions, individual behavior is assumed to be influenced by the general macroeconomic situation, cultural, religious and other (e.g. statistical) norms; these macro domains are displayed in the green boxes. 


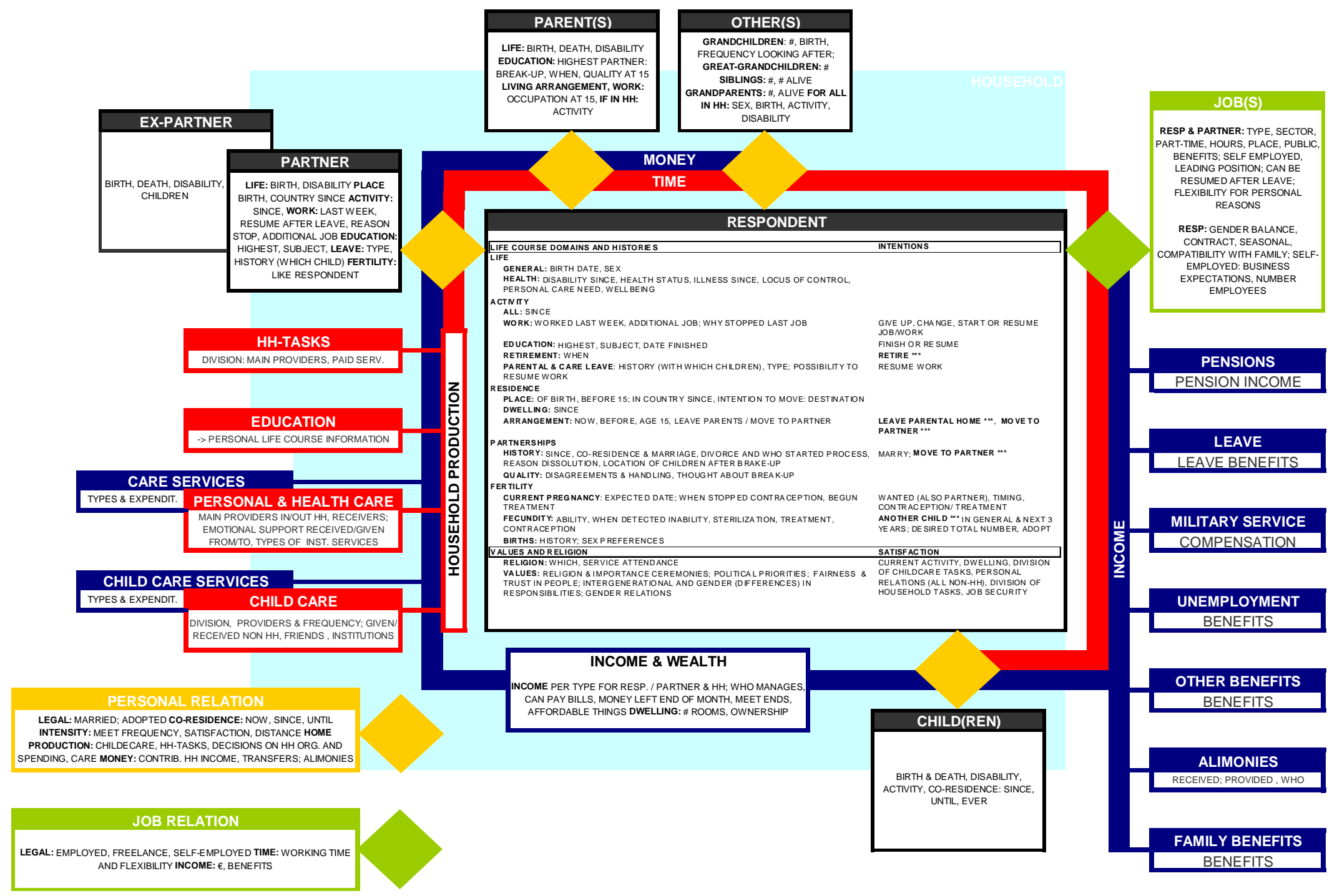




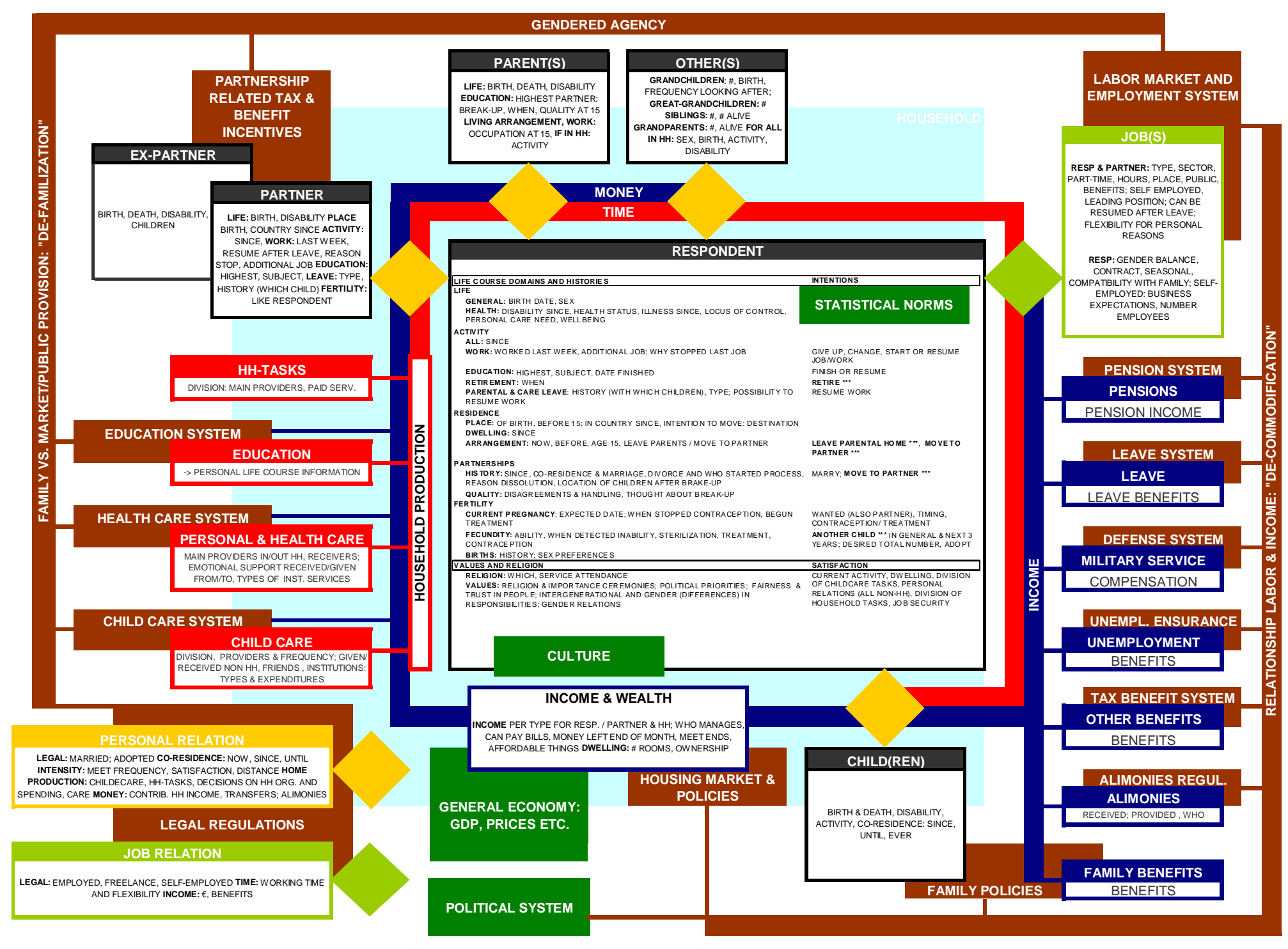




\section{Appendix: Existing policy data bases}

This document is a complement to the data inventory already compiled by the CDB group in 2002 which concentrates on relevant quantitative variables of 15 databases of ECE, LIS, Eurostat and OECD:

- UNECE-GDB Gender database

- UNECE-PAU Demographic Database

- UNECE-EDB Economic Database

- Eurostat NewCronos

- LIS Luxembourg Income Study

- LIS Family Policy Database

- OECD Main Economic Indicators

- OECD Labor force Statistics

- OECD Quarterly Labor Force Statistics

- OECD Labor Market Statistics

- OECD Non-Member Labor Market Database

- OECD Taxing Wages

- OECD Benefit and Wages (publication)

- OECD Education Database

- OECD Health Data

Databases added to this list in this document are

- SOFI SCIP Database, Stockholm University

- US Social Security Administration: Social Security throughout the world

- MZES Family Policy Database

- EUROMOD microsimulation model

- Comparative Maternity, Parental and Childcare Database (Gauthier)

- MISSOC

- Comparative Family Benefits Database (Gauthier)

- OECD/LIS Family Policy Database (new edition)

- Women in Decision Making Database

- The Clearinghouse on International Developments in Child, Youth and Family Policies at COLUMBIA UNIVERSITY

\subsection{Introduction: ways to collect policy data}

Policies can be analyzed in several dimensions and at different levels. Bahle \& Maucher (1998) distinguish between (1) social values and normative concepts; (2) political actors; (3) the administrative organization -most relevant in the context of policy databases: (4) single policy measures including institutional regulations (benefits and service provision, 
entitlement conditions, benefit rates, access to services) and (5) financing and social expenditures, the latter being distinguished by functional perspectives (focusing on purpose: old age, health, unemployment, family, survivors, disability, existence minimum) and institutional perspectives (who provides which benefits). Finally,(6) the policy impact: the expected outcomes of policies on income and behavior.

The main focus of the $\mathrm{CDB}$ is on policies and policy dimensions that impact the timing, sequencing and synchronization of life-course events studied in the GGS, e.g. by having an impact on the (gendered) consequences and risks associated with these central events, or by imposing age norms directly. (An example of the latter is the education system, or obligatory military service) Regarding the conceptual framework for the collection of policy data, comparative welfare-state research provides particularly useful concepts, as outlined in Neyer (2002). She developed three guidelines for data collection, referring to three (interrelated) central concepts of welfare state research:

- Agency: To what extent does the welfare state enable a person to enter into or exit from social and economic relationships?

- Equality: To what extent does the welfare state influence social and economic equalities? Korpi (2000) combines equality and agency concepts, when conceptualizing gender inequalities also in terms of gendered agency inequality, i.e. Korpi distinguishes between inequality of achievements and inequality in "terms of freedom to achieve". (Korpi 2000, p128).

- Rights: To what extent does the welfare state influence a person's social, economic and personal rights?

The following section gives an overview of 12 existing policy databases, that can both serve as examples and data sources for the $\mathrm{CDB}$ and show the variety of possible approaches to collect policy data.

\subsection{SCIP Database: quantitative social citizen indicators using type cases}

The SCIP (Social Citizen Indicator Program) database developed at the Swedish Institute for Social Research (SOFI) includes institutional information on social rights legislation in 18 OECD countries ${ }^{5}$ from 1930 to the present. The core database is organized into five central sections: (1) old-age pensions, (2) unemployment, (3) sickness insurance, (4) work accident insurance and (5) child allowances. The basic principle for inclusion of a program is that benefits are granted through legislation at the national level, as a social right $^{6}$.

\footnotetext{
${ }^{5}$ The countries are Australia, Austria, Belgium, Canada, Denmark, Finland, France, Germany, Ireland, Italy, Japan, the Netherlands, New Zealand, Norway, Sweden, Switzerland, the UK and the USA.

${ }^{6}$ Exceptions are made for the USA, Canada and Australia, where some schemes are legislated on a subnational level and are included in the data collection.
} 
Additional information not yet coded was collected on parental leave benefits including earnings-related parental insurance programs, lump-sum maternity grants and flat-rate childcare leave benefits paid after the termination of parental insurance (Ferrarini 2003).

Data are collected for fixed points in time, i.e. January of every fifth year. The database follows a type case approach, i.e. indicators and benefits are calculated for an average production worker in two alternative living arrangements: single and "male breadwinner couple" with two children. Replacement rates are then related to an "average production worker wage", More "typical cases" were constructed regarding child allowances (including income tax allowances, tax credits and cash transfers), namely the "male breadwinner couple" without children, two cases of double earner couples (with and without children) and three cases of $50 \%$ of average income worker being single, a "male breadwinner" without and with children. Beside its orientation to average production workers, the database also includes information on coverage, conditions, financing and minimum as well as maximum benefits.

The database consists of quantitative variables describing the systems contained. Regarding the social security system (pension, accident, sickness, unemployment), the main variable blocks are:

- Number of insured and reference population numbers (e.g. labor force)

- Coverage

- Waiting days

- Duration

- Conditions (reference period, contribution period, income ceiling, means-test, residence test, other conditions)

- Financing (insured person, state, employer, other)

- Replacement: Single (minimum, standard worker, full benefit, maximum benefit)

- Replacement: Couple (minimum, standard worker, full benefit, maximum)

- Average (pensions)

- Average production worker wage

Child and family allowances are captured in tax calculation sheets for an extended set of type cases. The SCIP database was and still is used and constructed over decades by welfare state researchers at SOFI and various publications - including Esping-Anderson

\footnotetext{
7 This approach is also used by the OECD in comparative studies of tax systems, e.g. „The Tax/Benefit Position of Production Workers“, OECD 1991 and was recently extended to eight family/household types. The most recent version of "Taxing Wages" is the 2002 CD-Rom database edition. Average wages used by OECD differ from the average wages in the SCIP database.
} 
(1980), Korpi (2000) - and various Ph.D. theses at SOFI, e.g. Ferrarini (2003), are based on this data collection. The SCIP database is currently not accessible to researchers outside of SOFI, although plans are under way to make access public when the documentation of the database is finished.

\subsection{OECD Taxing Wages Database}

Previously published as "The Tax/Benefit Position of Production Workers", the Taxing Wages Database provides internationally comparative data on direct tax levied on employees and their employers in all 30 Member countries of the OECD. These taxes include the employer's contributions to public social security and employee's contributions to public social security plus personal income tax. In addition, it specifies family benefits paid as cash transfers.

The amount of taxes and benefits are detailed program by program, for eight household types, which differ by income level and household composition. Results include the tax burden for one-and two-earner families. The most recent version of "Taxing Wages" is the 2002 CD-Rom database edition with data from 1979-2002; the database is not freely

accessible but can be ordered at http://www.oecdwash.org/PUBS/ELECTRONIC/epfin.htm. Older versions use two case types only, i.e. an average production worker being single versus being a married male breadwinner with two children.

\subsection{SSPTW Social Security Programs throughout world databases}

The SSPTW data collection of the US Social Security Administration is a structured description of the principal features of social security programs in more than 170 countries: old-age, survivors and disability; sickness and maternity; work injury; unemployment; and family allowances. Additionally, a set of tables provides information for each country on the types of social security programs, types of mandatory systems for retirement income, contribution rates and demographic and other statistics related to social security. The latest version (2002) of this data collection is available online at http://www.ssa.gov/policy/docs/progdesc/ssptw/. Data are periodically updated; the first version was published around 1940. Data for the 1995 edition and onwards is available to online subscribers under the title "Scheme Description database in Social Security Worldwide".

\subsection{The MZES Family Policy Database}

The European Family Policy Database was developed at the Mannheimer Zentrum für Europäische Sozialforschung (MZES) and is a collection of single family policy measures in 16 European countries from the 1960s until the mid-1990s. It is currently located at the Austrian Institute for Family Studies and available on CD-ROM (www.oif.ac.at). The measures are classified by 
- policy instruments: cash benefits, tax benefits, personal social services, benefits in kind, time rights;

- the main purpose/function: guaranteeing sufficient resources, childcare, housing, etc.; and

- the target group: families, children, spouses, mothers, surviving family members etc.

The database contains standardized descriptions of single policies and their changes over time, and provides extensive time series data regarding expenditures, service recipients, services provided (e.g. number of child care institutions etc.) Comparability of policy descriptions is ensured by common variable lists (of "standard variables") for single policy measures of a classification group.

Data were collected in hundreds of spreadsheets. (currently 180 measures with data collected on 252 excel spreadsheets) that can be retrieved by a database navigation system. The family policy database was developed in conjunction with the production of comparative country reports on family policies and was used to systematize data collection rather than having a wide spectrum of users in mind. This, together with maintenance problems, hampered a widespread use of the database.

\subsection{The Euromod microsimulation model}

The study of the behavioral responses to welfare state policies usually involves the evaluation of opportunity sets regarding their consequences on income and costs (including opportunity costs and time commitments). Regarding household income, this can be achieved by computing the effect of alternative behaviors (e.g. different numbers of working hours, take-up of parental leave benefits) on disposable income by means of microsimulation. This involves simulating tax and transfer amounts for all behavioral alternatives of interest of a given person in its family or household context. Various measures such as replacement rates or marginal tax rates can then be interpreted as "pressures on behavior" on the individual level and be used as covariates in the study of life course events or behavioral intentions as collected in the GGS. In microsimulation models, policies are transformed to accounting rules: these are computer language instructions that produce, for each unit, the provisions of existing or alternative tax and transfer systems, or other relevant institutional features. This approach is a logical extension of the case type approach allowing the calculations of all possible case types.

Euromod is a 15-country European-wide benefit-tax model, which is coordinated by the Microsimulation Unit of the Department of Applied Economics, Cambridge University. (see http://www.econ.cam.ac.uk/dae/mu/emod.htm). Recent projects and studies include the 'Employment Transitions in 13 European Countries', the 'Child-Targeted Tax-Benefit Reform in Spain in a European Context' and MICRESA ("Micro-Level Analysis of the European Social Agenda") 


\subsection{The Clearinghouse on International Developments in Child, Youth and Family Policies at COLUMBIA UNIVERSITY}

The Clearinghouse on International Developments in Child, Youth and Family Policies at COLUMBIA UNIVERSITY (see http://childpolicyintl.org/) is a collection of dozens of cross-sectional cross-national tables from various sources (and therefore also a good source of references.) The Clearinghouse provides comparative information on the policies, programs, benefits and services available in 23 advanced industrialized countries to address child, youth and family needs.

\subsection{Comparative Maternity, Parental and Childcare Database (by Gauthier \& Bortnik)}

The Comparative Maternity, Parental and Childcare Database was developed by Gauthier \& Bortnik (2001) at the University of Calgary and is available online at http://www.soci.ucalgary.ca/fypp/family_policy_databases.htm. It covers 22 OECD countries for the period 1970-1999. The database currently contains seven variables and attached country specific notes. The variables are:

- Maternity/parental leave duration (in weeks)

- Number of weeks of maternity/parental leave prior to childbirth

- Number of weeks of maternity/parental leave after childbirth

- Maternity/parental leave benefits (expressed as a percentage of women's wages in manufacturing; for flat rate benefits average female wages in manufacturing and average female hours worked are used);

- Childcare leave duration (in weeks)

- $\quad$ Type of childcare benefits (flat rate; $\%$ of earnings, $\%$ of unemployment benefits))

- Total duration of leave under both the maternity/parental and childcare leave schemes (in weeks)

The data collection is based on published data of the Council of Europe (1999), the International Labour Office (1988, 1994), -> MISSOC (serial) and the US Social Security Administration (-> Social Security Programs throughout the World)

\subsection{MISSOC - MISSCEEC}

The Mutual Information System on Social Protection contains comparative tables on Social Protection in the EU Member States and the European Economic Area and - under the name MISSCEEC for Eastern European Countries (Bulgaria, Czech Republic, Estonia, Hungary, Latvia, Lithuania, Poland, Romania, Slovak Republic and Slovenia). The database gives detailed descriptions of the following systems:

- Health care 
- $\quad$ Sickness - cash benefits

- Maternity

- Invalidity

- Old-age

- Survivors

- Employment injuries and occupational diseases

- Family benefits

- Unemployment

- Guaranteeing sufficient resources

- Long-term Care

Data were collected first for 1999 and are updated yearly describing the situation on the $1^{\text {st }}$ of January of a given year. Data are available online for the years 2002 and 2003 at http://europa.eu.int/comm/employment_social/missoc/index_en.html

\subsection{Comparative Family Benefits Database (by Gauthier)}

The Comparative Family Benefits Database was developed by Gauthier (2003) on the basis of published data. It covers 22 OECD countries and the period 1970-2000. The database contains data on family benefits as well as other background demographic and economic data. The focus is on cash benefits, including family allowances and tax relief for children and on the provision of pre-primary schools. The database is available online at http://www.soci.ucalgary.ca/fypp/family policy databases.htm and contains 17 variables.

- Total fertility rate

- Family allowances for the first, second and third child (type cases with children being of age $12,10 \& 12$ resp. $8 \& 10 \& 12$ )

- Value of tax and benefit transfers to a two-child family (in real value, using OECD type cases of average industrial workers)

- Index of disposable income (Value of tax and benefit transfers to a two-child family in relation to a average industrial worker's wage)

- Female wages and male wages

- Purchasing power parity

- Consumer Price Index

- Percentage working in agriculture

- Female labor-force participation

- Unemployment rate

- Infant mortality rate

- Average gross earnings of a production worker 
- Expenditures on family allowances (as \% GDP)

- Gross enrolment ratio in pre-primary education

Main data sources are OECD Historical Statistics (various issues). -> MISSOC (serial) and the US Social Security Administration (-> Social Security Programs throughout the World), -> OECD taxing wages and the ILO International Labor Office Year Book of Labor Statistics (various years).

\subsection{OECD/LIS Family Policy Database}

This database was first developed by Janet Gornick at LIS (Luxembourg Income Studies) and is available in two versions for 1997 and 2003 at http://www.lisproject.org/publications/fampol/fampolaccess.htm. Currently, the database is extended and will be maintained and updated at OECD. Gornick focuses on the family policy package consisting of paid (maternity, paternity and health care) leave, working regulations and early childhood care. The data were collected for the purpose of comparative cross-sectional analysis of various behaviors, such as labor-marked participation of mothers of small versus older children. In her recent book "Family that work" (2003), which is based on this data collection, her focus is on the study of policy effects regarding the organization of family and work in the various welfare state regimes for the development of policy options in the US. Data are available for Australia, Belgium, Canada, Denmark, Finland, France, Germany, Italy, Luxembourg, the Netherlands, Norway, Sweden, United Kingdom and the United States. The 2003 version of the database consists of 19 comparative tables:

- Family Leave Policies

- Maternity and Parental Leave Provisions

- Leave for Family Reasons

- Provisions for Fathers

- Family Leave Financing

- Maternity and Parental Leave Expenditures, per employed woman

- Working Time Regulations

- Establishment of Normal Working Hours

- Measures that Encourage Development of Voluntary Part-Time Employment and Improvement of the Quality of Part-Time Work

- Measures Influencing Employment During Nonstandard Hours (Evenings, Nights, Weekends)

- Regulation of Annual Paid Vacation Time, Approximately 2000 
- Early Childhood Education and Care (ECEC)

- Institutional Arrangements and Entitlements for Publicly Supported Early Childhood Education and Care,

- Enrollment in Publicly Supported Early Childhood Education and Care,

- Government Mechanisms for Financing Early Childhood Education and Care,

- Co-Payment Policies and Estimated Share of ECEC Costs Assumed by Government,

- Distribution of Parental Child Care Costs in France and the United States, Families with Employed Mother, US and France,

- Public Spending on Early Childhood Education and Care, per Child (2000 US\$ PPP-Adjusted),

- ECEC Quality Regulations,

- ECEC Staff Compensation,

- Hours and Days of Supervised Care,

The content of the database are "text-format" policy descriptions organized in ExcelSpreadsheets. Additionally, the database includes a Policy Index Workbook containing 22 indices:

Early Childhood and Care

- guaranteed slot for some children 0-1-2 (yes, no)

- $\quad$ enrollment in public care < age $1(\%$ of age group)

- enrollment in public care age 1-2 (\% of age group)

- cost to parents if children in public care age 1-2 (\% of total cost)

- $\quad$ enrollment in public care age 3-4-5 (\% of age group)

- cost to parents if children in public care age 3-4-5 (\% of total cost)

- typical hours age 3-4-5 (full-day, mixed, part-day)

- enrollment age 6 (if compulsory school at 7) (\% of age group)

- quality (low, medium, high)

- tax relief for ECEC (yes, no)

- School Scheduling

- $\quad$ starting age (age)

- hours per day (hours)

- days per year (days) 
- continuity of school day (yes, no, sometimes)

- Family Leave

- weeks of full-pay available to mothers (weeks)

- paid paternity leave (yes, no)

- gender equality scale / incentives for fathers (see below)

- $\quad$ some paid leave after 3rd birthday (yes, no)

- paid sick child leave (yes, no)

- expenditures on leave (2000 \$US/employed woman)

- Working Time

- normal weekly hours (hours)

- normal vacation time (days)

\subsection{Women in Decision-Making Database}

The European Database Women in Decision-Making provides information about women in political decision-making positions in the European Union, in member states of the European Economic Area and candidate countries. Data are collected on the national, regional and European level and available at http://www.db-decision.de/index E.htm. The European Women in Decision-Making Database is funded within the framework of the 4th EU Action Programme on Equal Opportunities by the European Commission and various German ministries, and contains information on women in politics in national and regional governments and parliaments, the European Parliament, the European Commission and other selected European Institutions. 


\section{References}

Council of Europe (1999) Comparative Tables of the Social Security Schemes, - 9th edition

International Labour Office (1988). Work and Family: The Childcare Challenge. Conditions of Work Digest. Volume 7. Geneva

International Labour Office (1994). Maternity and Work. Conditions of Work Digest. Volume 13. Geneva: International Labour Office

European Commission (serial) MISSOC, Social Protection in the Member States of the Community. http://europa.eu.int/comm/employment_social/soc-prot/missoc99/english/f_main.htm

US SSA (serial) Social Security Programs throughout the World. Washington, D.C : U.S. Dept. of Health, Education, and Welfare, Social Security Administration, Division of Program

Gauthier, A.H. (2003). Comparative Family Benefits Database, Version 2 (University of Calgary).

Goldscheider, Frances K (2000) Realizing the Potential of FFS1 with Contextual Data, Presentation at the FFS Flagship Conference 2000, http://www.unece.org/ead/pau/flag/papers/goldscheider.pdf

Festy, Patrick (2001) Designing a Macro-Context for the Generations and Gender Individual Data, Presentation at the first meeting of the Informal Working Group of the Generations and Gender Program in Budapest 2001 http://www.unece.org/ead/pau/ggp/fmiwg/festy.pdf.

Neyer, Gerda (2002) Generations and Gender Dimensions in Welfare-State Policies, http://www.unece.org/ead/pau/ggp/smiwg/cdbasegr.pdf

Racioppi, Filomena \& Rivellini, Giulia (2002) The contextual dimension in GGP: some methodological issues about data collection and sampling procedures http://www.unece.org/ead/pau/ggp/smiwg/cdbasegr.pdf

Festy, Patrick (2004) GGP Contextual database group: first discussions, first conclusions; available from the author: festy@ined.fr

Korpi, Walter (2000) Faces of Inequality: Gender, Class, and Patterns of Inequalities in Different Types of Welfare States; Social Policies, Summer 2000

Esping-Andersen Gosta (1990) Three Worlds of Welfare Capitalism; Polity Press, Cambridge

Ferrarini, Tommy (2003) Parental Leave Institutions in 18 Post-War Welfare States; Swedish Institute for Social Research, Dissertation Series 58 